\title{
ENTREPRENEURIAL FORESIGHT: ROLE OF FORESIGHT IN ENTREPRENEURIAL OPPORTUNITY RECOGNITION
}

\author{
By \\ Ali Hajizadeh \\ Bachelor of Science in Small Business Management, University of Tehran, 2011 \\ Master of Science in Entrepreneurship, University of Tehran, 2014
}

\author{
A thesis \\ presented to Ryerson University \\ in partial fulfillment of the \\ requirements for the degree of \\ Master of Science in Management \\ in the program of \\ Master of Science in Management
}

Toronto, Ontario, Canada, 2019

(C) Ali Hajizadeh, 2019 


\section{AUTHOR'S DECLARATION}

I hereby declare that I am the sole author of this thesis. This is a true copy of the thesis, including any required final revisions, as accepted by my examiners.

I authorize Ryerson University to lend this thesis to other institutions or individuals for the purpose of scholarly research.

I further authorize Ryerson University to reproduce this thesis by photocopying or by other means, in total or in part, at the request of other institutions or individuals for the purpose of scholarly research.

I understand that my thesis may be made electronically available to the public. 
Entrepreneurial Foresight: Role of Foresight in Entrepreneurial Opportunity Recognition

Ali Hajizadeh

Master of Science in Management, 2019

Ryerson University

\begin{abstract}
Opportunity recognition, as the first step of venture creation and business development, plays an essential role in entrepreneurship. Previous research studied various factors that can influence opportunity recognition, but they failed to consider the potential role of foresight in this process. Thus, this research aimed to explore whether and how individuals apply foresight to identify entrepreneurial opportunities. In order to answer the research questions, qualitative research was designed and semi-structured interviews were employed for collecting the data from 16 participants including entrepreneurs and non-entrepreneurs who search for business opportunities. Thematic analysis method was used for identifying and analyzing meaningful patterns within the data set. The findings showed that the majority of participant tend to be future-oriented during opportunity recognition. Also, the results provided significant themes that demonstrate how the participants apply foresight to identify more and better opportunities.
\end{abstract}




\section{Acknowledgement}

I would first like to express my sincere gratitude to my supervisor, Dr. Dave Valliere, for his guidance and support. He allowed this paper to be my own work, but steered me in the right direction whenever he thought I needed it. I am also grateful to Ryerson University and Ted Rogers School of Management that gave me the chance to pursue my second master's degree. I am thankful to the professors and administrative staff at TRSM who assisted me during the program. Finally, I wish to appreciate my parents for their encouragement and support throughout this journey. 


\section{Table of Contents}

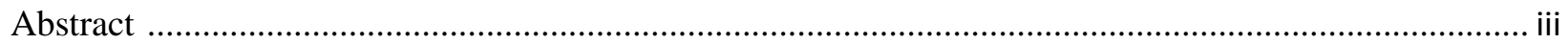

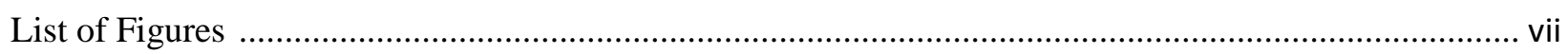

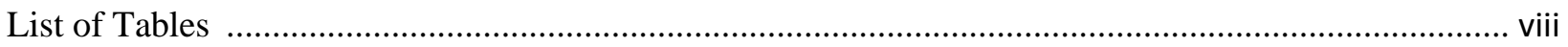

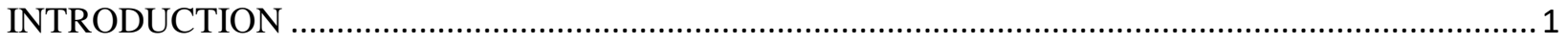

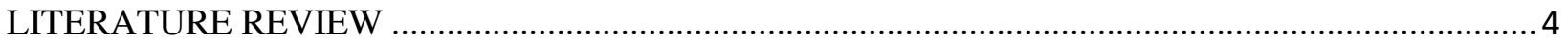

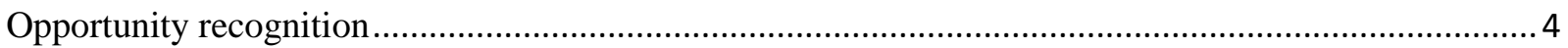

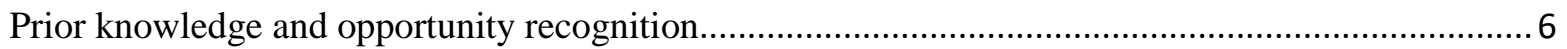

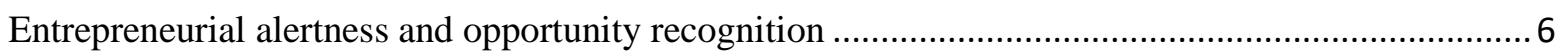

Entrepreneurial learning and opportunity recognition ............................................................. 7

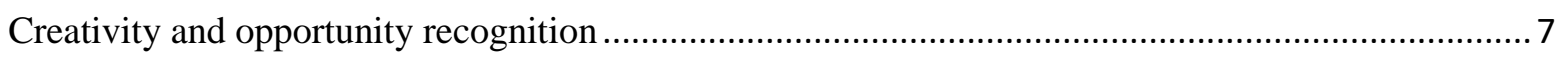

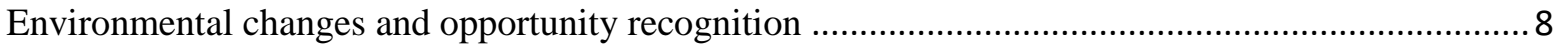

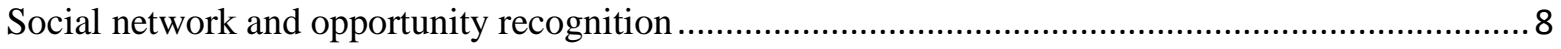

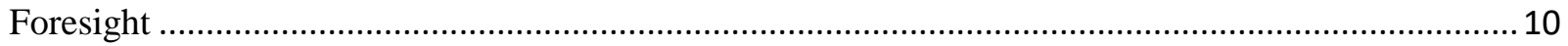

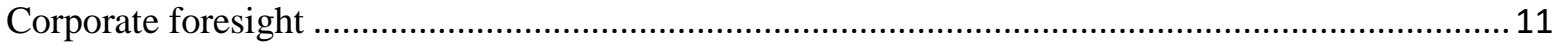

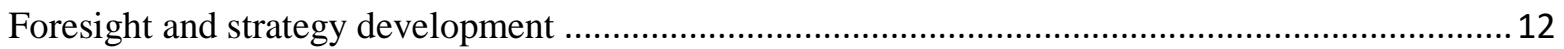

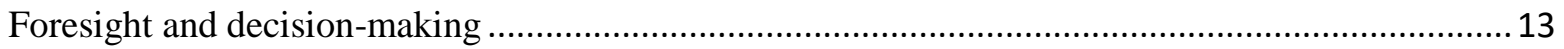

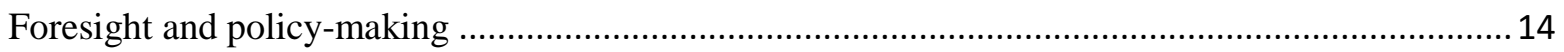

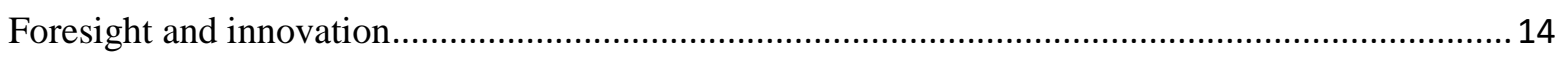

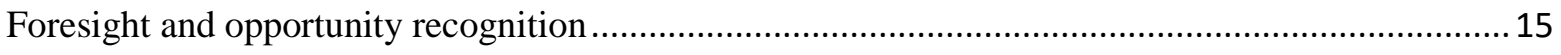

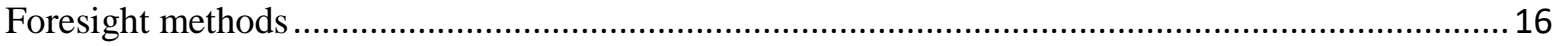

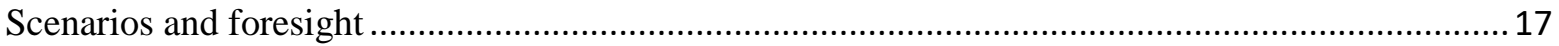

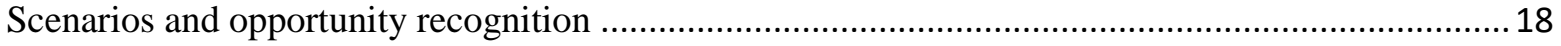

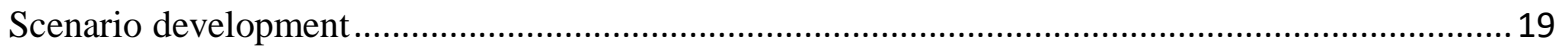

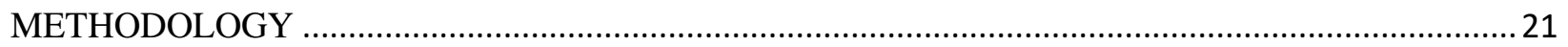

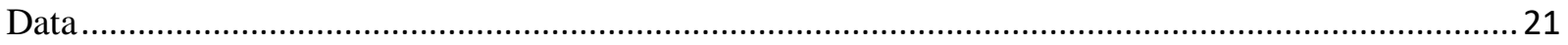

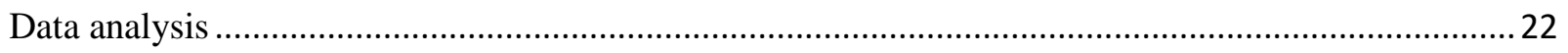

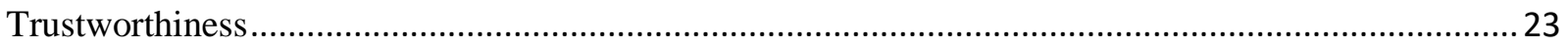

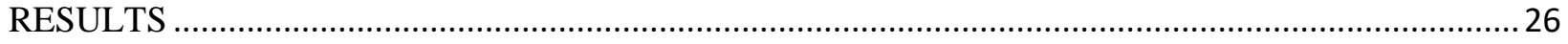

Future-orientation in entrepreneurial opportunity recognition ...................................................... 26

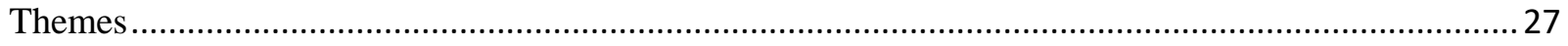

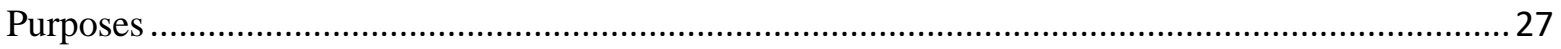

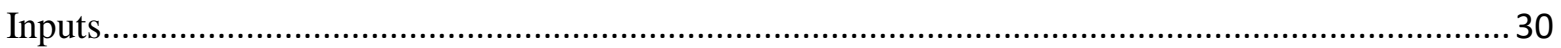




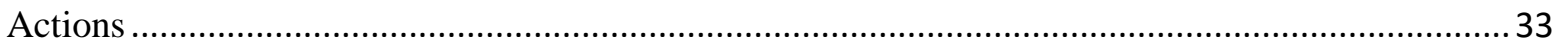

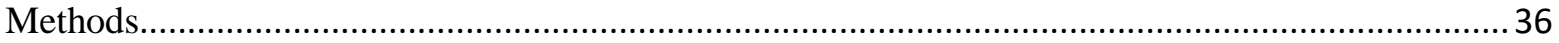

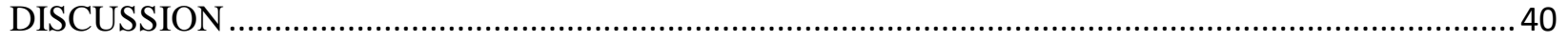

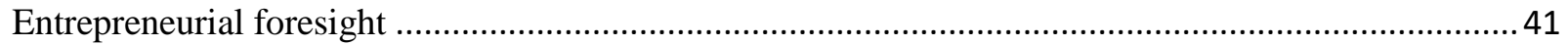

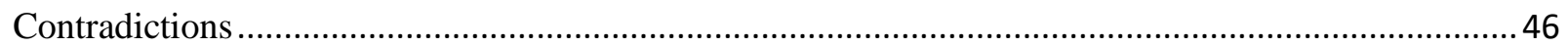

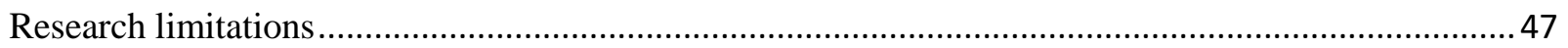

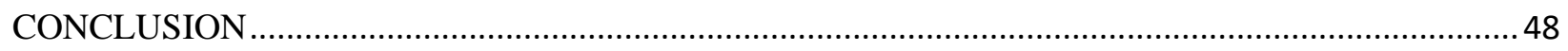

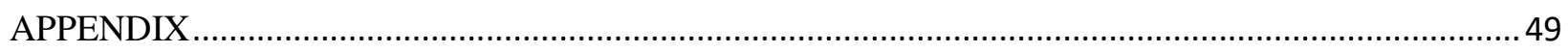

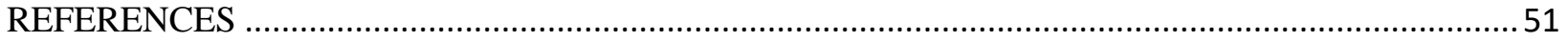




\section{List of Figures}

Figure 1 - Development of the Corporate Foresight research stream (adapted from Rohrbeck et al., 2015)

Figure 2 - Foresight Methods - (adapted from Popper, 2008b) .......................................................... 17

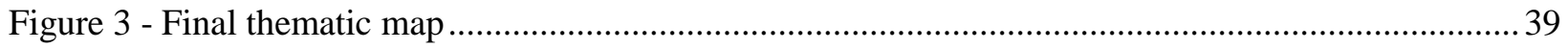

Figure 4 - Entrepreneurial Foresight Process .................................................................................... 45 


\section{List of Tables}

Table 1 - Key Factors in Entrepreneurial Opportunity Recognition .................................................... 9 


\section{INTRODUCTION}

Opportunity recognition, as the first step of venture creation and business development, plays an essential role in entrepreneurship. According to definitions that describe opportunity as the core of the entrepreneurship, an entrepreneur is a person who identifies, evaluates and exploits opportunities (Shane, 2003; Venkataraman, 1997). The most important questions that may come to minds is why and how some individuals are able to identify opportunities that have been overlooked by others.

In order to answer this question, researchers have identified various factors that may contribute to the opportunity recognition skill. These factors can be categorized into personal elements such as prior knowledge and experience (Shane, 2000; Ardichvili and Cardozo, 2000), entrepreneurial alertness (Tang et al., 2012; Kirzner, 1979) entrepreneurial learning (Corbett, 2007; Hajizadeh and Zali, 2016), creativity (Hansen et al., 2011; Shane, 2003), and external elements like environmental changes and trends (Baron, 2006; Eckhardt and Shane, 2003) and social networks (Singh, 2000; Ozgen and Baron, 2007).

One of the potential origins of opportunity for entrepreneurs is the future which has not received enough attention from scholars. Many different types of business opportunities can emerge from future trends and developments. So, it is necessary to conduct a research study about the importance of the future in the opportunity identification process. Foresight is one of the major means that enables individuals and firms to explore the future and think ahead of time. Over the last decade, much attention has been paid to this subject by researchers. Most of them regarded foresight as a corporate capability or practice that helps companies cope with uncertainty and complexity of the future. The previous studies mostly discussed the role of different strategic fields such as decision-making (Cook et al., 2014; Vecchiato, 2012), strategy development (Darkow, 
2015; Heiko et al., 2010), policy-making (Da Costa and et al., 2011; Havas et al., 2010), and innovation (Rohrbeck and Gemünden, 2011; Georghiou and Harper, 2011).

However, this study proposes a new perspective on foresight which concentrates on the potential role of foresight in the entrepreneurial opportunity recognition. Lack of an opportunityoriented perspective to foresight in previous studies implies that scholars have overlooked the entrepreneurial aspect of foresight. In other words, the dominant uncertainty-oriented perspective mainly underlines the strategic application of foresight used for dealing with threats; but the opportunity-oriented perspective highlights foresight's entrepreneurial function considered for identifying business opportunities. Therefore, the main purpose of this research is to study whether and how opportunity seekers apply foresight to discover opportunities.

Researchers discussed different foresight methods such as trend analysis, scenarios, Delphi technique, road-mapping, etc. (Pinter, 2013; Will, 2008). Among these methods, scenario development as one of the most common and helpful methods, which enables individuals to build a coherent and plausible picture of the future (Bishop et al., 2007), is more associated with opportunity recognition. Schoemaker (1995) states that scenarios could have seeds of new business opportunities. So, in order to acquire a better understanding of foresight role in opportunity recognition, scenario development is investigated particularly.

This study makes three main original contributions to the fields. First, it shows the significance of the future and the role foresight in opportunity recognition process. Secondly, it offers a new perspective on foresight which exposes its opportunity-related function. Thirdly, it demonstrates how foresight works in the process of opportunity recognition. In term of practical contributions, the process of entrepreneurial foresight could be considered as a toolkit that would enable opportunity seekers to discover more and better business opportunities. 
This research consists of four main sections. First, it reviews the literature relevant to the area of research in order to provide an overview of discussions, theories, and findings about the topic and to identify the research problem. In the methodology section, it discusses the research approach, data collection method and process, and data analysis technique. In the third part, the significant findings are demonstrated. Finally, the findings are interpreted with the aim of explaining how they address the research questions. 


\section{LITERATURE REVIEW}

The literature review section includes four major sections. First, entrepreneurial opportunity recognition and key factors that impact this process have been reviewed. Secondly, foresight and its implications in different areas have been discussed. Then, foresight methods and scenario development as one of the most common and opportunity-related techniques have been investigated. Finally, the review has been summarized by explaining the major gap identified in the literature.

\section{Opportunity recognition}

Generally, there are two approaches to entrepreneurial opportunities: opportunity recognition and opportunity construction. Although these two approaches have much in common, there are some differences. The first approach assumes that individuals search and discover opportunities that are formed by external factors and already exist in the environment. However, the latter suggests that individuals themselves create opportunities by acting (Alvarez and Barney, 2007). In other words, in the exogenous approach, opportunities are objective in nature; but in the endogenous approach, opportunities are subjective. In the opportunity recognition process, market and industry information is obtainable and analyzed for identifying opportunities. On the other hand, the opportunity construction process happens under uncertainty in which information required to form opportunities does not exist. So, entrepreneurs have to begin a range of blind actions, reactions, and enactments that may lead to creation of opportunities.

Effectuation (Sarasvathy, 2001) is one of the entrepreneurship theories that assumes entrepreneurs construct opportunities during entrepreneurial activities. According to this theory, entrepreneurs acting under extreme uncertainty focus mostly on controllable aspects (e.g., means, skills, social networks) rather than predictable aspects of the future. Therefore, effectuators use 
their set of means and aspirations in order to suppose a set of possible effects (i.e., future options) and then choose one based on level of affordable loss or acceptable risk (Sarasvathy, 2001). Since this opportunity development process is actor-based, the opportunities (i.e., ends) are subjective and may alter as the actors and means may change. So, unlike causation logic, effectuation logic does not consider opportunities as objective targets that can be recognized. However, this research takes recognition approach to entrepreneurial opportunities as it matches better with foresight concept.

Opportunity recognition is considered a key step in the process of entrepreneurship and venture creation (Baron, 2006; Ardichvili et al., 2003; Shane, 2000). Shane and Venkataraman (2000) believe entrepreneurial opportunities exist because individuals have different conjectures which are based on their asymmetric information, perceptions, expectations, and beliefs. Entrepreneurial opportunity is 'situations in which new goods, services, raw materials, markets, and organizing methods can be introduced through the formation of new means, ends, or meansends relationships' (Eckhardt and Shane, 2003, p. 336). Ardichvili et al. (2003) stated that opportunity recognition process contains spotting market needs, finding a fit and creating a new "fit" between the needs and particular resources.

Researchers have identified various factors that may contribute to opportunity recognition. These factors can be categorized into personal elements such as prior knowledge and experience (Shane, 2000; Ardichvili and Cardozo, 2000), entrepreneurial alertness (Tang et al., 2012; Kirzner, 1979) entrepreneurial learning (Corbett, 2007; Hajizadeh and Zali, 2016), Creativity (Hansen et al., 2011; Shane, 2003), and external factors like environmental changes and trends (Baron, 2006; Eckhardt and Shane, 2003) and social networks (Singh, 2000; Ozgen and Baron, 2007). Baron (2006) explained that opportunity recognition is a cognitive process in which people use specific 
frameworks to identify the patterns that lead to potential business opportunities. However, Fiet (2007) asserted that opportunity discovery is a constrained and systematic search process that can be improved by entrepreneurs.

\section{Prior knowledge and opportunity recognition}

Prior knowledge is one most important factors in entrepreneurial opportunity recognition (Shane, 2000; Ardichvili et al., 2003; Alsos and Kaikkonen, 2004; Shepherd and DeTienne, 2005; Baron, 2006; Marvel and Lumpkin, 2007). Prior knowledge refers to the knowledge in a specific domain, which can be a result of work experience, education and other means (Shepherd and DeTienne, 2005). Venkataraman (1997) mentioned that prior information and knowledge is a critical source of opportunities for entrepreneurs and they are only able to identify opportunities that are related to their prior knowledge. Also, according to studies, prior knowledge about market, customer problem, and ways of serving market needs play a significant role in opportunity recognition (Ardichvili and Cardozo, 2000; Ardichvili et al., 2003). Marvel and Lumpkin (2007) indicated that prior technology knowledge helps entrepreneurs to discover more opportunities in their field.

\section{Entrepreneurial alertness and opportunity recognition}

Many researchers emphasized on the importance of entrepreneurial alertness in process of opportunity identification (Baron, 2006; Ardichvili et al., 2003; Kirzner, 1973; Gaglio and Katz, 2001; Tang et al., 2012; Valliere, 2013). Entrepreneurial alertness is a perceptual and cognitive processing capability that enables an entrepreneur to identify opportunities that have been neglected by others. (Gaglio and Katz, 2001). Ardichvili and Cardozo (2000) argued that entrepreneurs show a high level of awareness of information and environmental changes during opportunity recognition. Some researchers believe entrepreneurial alertness is deliberate searching 
and scanning the environment rather than a cognitive skill (Tang et al., 2012; Kaish and Gilad, 1991). According to Tang et al. (2012), entrepreneurial alertness is a process contains three different stages including scanning and searching, association and connections, and evaluation and judgment.

\section{Entrepreneurial learning and opportunity recognition}

Another influential factor in opportunity recognition process is entrepreneurial learning (Dimov, 2007; Corbett, 2005, 2007; Politis, 2005; Wing Yan Man, 2006; Hajizadeh and Zali, 2016). Entrepreneurial learning is a cognitive ability to acquire knowledge and experience, and employ them to discover opportunities (Wing Yan Man, 2006; Dimov, 2007). Corbett (2005) in his study argued that learning approach (knowledge acquisition and processing) can affect opportunity identification process. Another research showed that entrepreneurial learning helps entrepreneurs to exploit their prior knowledge in order to discover more entrepreneurial opportunities (Hajizadeh and Zali, 2016). Besides, Politis (2005) pointed out that cognitive process of learning aid entrepreneurs with identifying opportunities by creating entrepreneurial knowledge from work experience.

\section{Creativity and opportunity recognition}

Many researchers have investigated the relationship between creativity and opportunity recognition (Schumpeter, 1934; Ardichvili et al., 2003; Hansen et al., 2011; Heinonen et al., 2011). Schumpeter (1934) stated that successful entrepreneurs use creativity to discover new opportunities. Also, Ardichvili et al. (2003) believe creativity is one of the significant personal traits in the opportunity recognition process. According to a creative-based model of opportunity recognition, creativity has a positive impact on the opportunity identification process (Hansen et 
al., 2011). Moreover, a study suggested that creativity helps individuals enhance opportunity search strategies and find more viable business ideas (Heinonen et al., 2011).

\section{Environmental changes and opportunity recognition}

Researchers suggested that change is an essential component of opportunity recognition process (Alsos and Kaikkonen, 2004). Fiet (2007) believes that being alert to signals about environmental changes and quick response to them is a key to opportunity identification. Also, Schumpeter (1934) and Shane (2000) argued that technological changes are the main sources of different kind of entrepreneurial opportunities. According to the pattern recognition framework, entrepreneurs use their cognitive capacity to connect dots between changes in market, technology, economic and so on (Baron, 2006). In fact, change in different factors produces new information that leads entrepreneurs to opportunities (Eckhardt and Shane, 2003).

\section{Social network and opportunity recognition}

Researchers showed that social network plays a considerable role in opportunity recognition process (Baron, 2006; Ardichvili et al, 2003; Ozgen and Baron, 2007). Social network as an important source of information provides entrepreneurs with knowledge developing their opportunity identification ability (Baron, 2006). Hills et al. (1997) in their study demonstrated that the broader social network, the more opportunities entrepreneurs discover. A study indicated that all of the three social sources of opportunity-related information including mentors, informal industry network, and professional forums have a positive impact on opportunity recognition (Ozgen and Baron, 2007). Singh (2000) argued that the entrepreneurs who utilize their social networks identify not only more opportunities but a wider range of opportunities. 


\begin{tabular}{|c|c|c|}
\hline Author \& Year & Title & Key factors \\
\hline Baron (2006) & $\begin{array}{l}\text { Opportunity recognition as pattern } \\
\text { recognition: How entrepreneurs connect the } \\
\text { dots to identify new business opportunities }\end{array}$ & $\begin{array}{l}\text { Environmental changes, Social } \\
\text { network, Prior knowledge, } \\
\text { Entrepreneurial alertness, Active } \\
\text { search }\end{array}$ \\
\hline $\begin{array}{l}\text { Ardichvili et al. } \\
(2003)\end{array}$ & $\begin{array}{l}\text { A theory of entrepreneurial opportunity } \\
\text { identification and development }\end{array}$ & $\begin{array}{l}\text { Personal traits, Social network, } \\
\text { Prior knowledge, } \\
\text { Entrepreneurial alertness }\end{array}$ \\
\hline Shane (2000) & $\begin{array}{l}\text { Prior knowledge and the discovery of } \\
\text { entrepreneurial opportunities }\end{array}$ & $\begin{array}{l}\text { Technological changes, Prior } \\
\text { knowledge }\end{array}$ \\
\hline $\begin{array}{l}\text { Shane and } \\
\text { Venkataraman } \\
(2000)\end{array}$ & $\begin{array}{l}\text { The promise of entrepreneurship as a field } \\
\text { of research }\end{array}$ & $\begin{array}{l}\text { Cognitive characteristics, Prior } \\
\text { knowledge }\end{array}$ \\
\hline $\begin{array}{l}\text { Eckhardt and Shane } \\
\text { (2003) }\end{array}$ & Opportunities and entrepreneurship & Environmental changes \\
\hline $\begin{array}{l}\text { Ardichvili and } \\
\text { Cardozo (2000) }\end{array}$ & $\begin{array}{l}\text { A model of the entrepreneurial opportunity } \\
\text { recognition process }\end{array}$ & $\begin{array}{l}\text { Prior knowledge, } \\
\text { Entrepreneurial alertness }\end{array}$ \\
\hline Tang et al. (2012) & Alertness in the pursuit of new opportunities & $\begin{array}{l}\text { Entrepreneurial alertness, Prior } \\
\text { knowledge }\end{array}$ \\
\hline $\begin{array}{l}\text { Hajizadeh and Zali } \\
\text { (2016) }\end{array}$ & $\begin{array}{l}\text { Prior knowledge, cognitive characteristics } \\
\text { and opportunity recognition }\end{array}$ & $\begin{array}{l}\text { Prior knowledge, } \\
\text { Entrepreneurial learning, } \\
\text { Entrepreneurial alertness }\end{array}$ \\
\hline Corbett (2007) & $\begin{array}{l}\text { Learning asymmetries and the discovery of } \\
\text { entrepreneurial opportunities }\end{array}$ & $\begin{array}{l}\text { Prior knowledge, } \\
\text { Entrepreneurial learning }\end{array}$ \\
\hline $\begin{array}{l}\text { Alsos and } \\
\text { Kaikkonen (2004) }\end{array}$ & $\begin{array}{l}\text { Opportunities and prior knowledge: A study } \\
\text { of experienced entrepreneurs }\end{array}$ & $\begin{array}{l}\text { Environmental changes, Prior } \\
\text { knowledge }\end{array}$ \\
\hline $\begin{array}{l}\text { Shepherd and } \\
\text { DeTienne (2005) }\end{array}$ & $\begin{array}{l}\text { Prior knowledge, potential financial reward, } \\
\text { and opportunity identification }\end{array}$ & $\begin{array}{l}\text { Prior knowledge, Potential } \\
\text { financial reward }\end{array}$ \\
\hline $\begin{array}{l}\text { Marvel and } \\
\text { Lumpkin (2007) }\end{array}$ & $\begin{array}{l}\text { Technology entrepreneurs' human capital } \\
\text { and its effects on innovation radicalness }\end{array}$ & Prior knowledge \\
\hline $\begin{array}{l}\text { Giglio and Katz } \\
(2001)\end{array}$ & $\begin{array}{l}\text { The psychological basis of opportunity } \\
\text { identification: Entrepreneurial alertness }\end{array}$ & Entrepreneurial alertness \\
\hline Dimov (2007) & $\begin{array}{l}\text { Beyond the single-person, single-insight } \\
\text { attribution in understanding entrepreneurial } \\
\text { opportunities }\end{array}$ & $\begin{array}{l}\text { Creativity, Entrepreneurial } \\
\text { learning, Social network }\end{array}$ \\
\hline Corbett (2005) & $\begin{array}{l}\text { Experiential learning within the process of } \\
\text { opportunity identification and exploitation }\end{array}$ & $\begin{array}{l}\text { Entrepreneurial learning, } \\
\text { Creativity, Knowledge }\end{array}$ \\
\hline Schumpeter (1934) & Capitalism, socialism, and democracy & $\begin{array}{l}\text { Creativity, Environmental } \\
\text { changes }\end{array}$ \\
\hline
\end{tabular}




\begin{tabular}{|l|l|l|}
\hline \multicolumn{1}{|c|}{ Author \& Year } & \multicolumn{1}{|c|}{ Title } & \multicolumn{1}{c|}{ Key factors } \\
\hline Hansen et al. (2011) & $\begin{array}{l}\text { A multidimensional examination of a } \\
\text { creativity-based opportunity recognition } \\
\text { model }\end{array}$ & Creativity \\
\hline Fiet (2006) & $\begin{array}{l}\text { A prescriptive analysis of search and } \\
\text { discovery }\end{array}$ & $\begin{array}{l}\text { Prior knowledge, Environmental } \\
\text { changes, Systematic search }\end{array}$ \\
\hline $\begin{array}{l}\text { Ozgen and Baron } \\
\text { (2007) }\end{array}$ & $\begin{array}{l}\text { Social sources of information in opportunity } \\
\text { recognition: Effects of mentors, industry } \\
\text { networks, and professional forums }\end{array}$ & $\begin{array}{l}\text { Social network, Self-efficacy, } \\
\text { Schema strength }\end{array}$ \\
\hline Singh (2000) & $\begin{array}{l}\text { Entrepreneurial opportunity recognition } \\
\text { through social networks }\end{array}$ & Social network \\
\hline
\end{tabular}

\section{Foresight}

Foresight is one of the key terms in future studies which has become more popular among researchers over the last decade. Foresight refers to a capability to know the future and to plan your actions based on this knowledge. The concept of foresight is built on three assumptions: 1) multiple futures are possible, 2) change can be recognized and studied, 3) future can be influenced (Rohrbeck et al., 2015). It is clear that foresight relates to the future and range of several possible futures that one of them can be the desirable future (Amsteus, 2008).

There is no close agreement on the conceptual definition of foresight. Major et al. (2001) believe foresight is an elusive term which has been misunderstood. They mentioned that this ambiguity can be due to different perspectives on foresight as a process, a personal capacity, a behavior, or a national program. Also, another reason for this confusion may be because of various focuses in research; such as studying foresight itself, investigating its antecedents, or exploring its outcomes and results (Amsteus, 2008).

In spite of the disagreements, most of the researchers emphasized the role of foresight in exploring the future. Horton (1999) defined foresight as "a process of developing a range of views of possible ways in which the future could develop, and understanding these sufficiently well to 
be able to decide what decisions can be taken today to create the best possible tomorrow" (P. 5). Tsoukas and Shepherd (2004) stated that foresight is an ability to spot changes and patterns before they emerge and shape future events. Also, Slaughter (1995) believes that foresight is a human ability that helps individual to think ahead, create, evaluate and response different possible futures and choose one of them.

Popper (2008a) identified nine common objectives of foresight exercises. The objectives include (1) fostering science, technology, innovation (STI), (2) networking and cooperation (3) recognizing key barriers and drivers of STI, (4) encouraging strategic and futures thinking, (5) supporting STI strategy-setting and priority-setting, (6) identifying research and investment opportunities, (7) generating visions and images of the future, (8) helping to cope with "Grand Challenges" (e.g., climate change, natural disasters, poverty, etc.), and (9) triggering actions and promoting public debate.

\section{Corporate foresight}

Most of the previous research studied foresight in a corporate level of analysis. The concept of corporate foresight generally refers to foresight activities within firms. Corporate foresight is "art of the long view" in the company (Schwarz, 1991). Rohrbeck et al. (2015) defined corporate foresight as a practice that allows managers to identify changes, prepare the organization for the changes and act proactively toward a desirable future in order to achieve competitive advantages. Corporate foresight is also identified as an exploration of future prospects in business environments, markets and technologies and their implications for the organization (Ruff, 2006). In fact, corporate foresight enables organizations to deal with environmental changes by considering the complexity and dynamics of future forces (Heiko et al., 2010). Rohrbeck (2012)

pointed out that corporate foresight helps managers to continuously monitor the external 
environment, so they can identify relevant changes and find new resources. Will (2008) believes corporate foresight is a process of communication to build a long-term vision on future markets, customer needs, and social changes. Moreover, corporate foresight increases companies' sensitivity to trends and weak signals and aids them in gaining knowledge about emerging markets (Battistella, 2014).

\begin{tabular}{|c|c|c|c|}
\hline $\begin{array}{l}\text { Birth of the Field } \\
1950 \text { s }\end{array}$ & $\begin{array}{c}\text { The Age of Scenarios } \\
1960 \mathrm{~s}-1970 \mathrm{~s}\end{array}$ & $\begin{array}{l}\text { Methods and Process } \\
1980 \mathrm{~s}-1990 \mathrm{~s}\end{array}$ & $\begin{array}{l}\text { Organizational } \\
\text { Integration } \\
2000 \text { to present }\end{array}$ \\
\hline $\begin{array}{l}\text { - Gaston Berger founds } \\
\text { the French "prospective" } \\
\text { school, centered around } \\
\text { the idea of collaborative } \\
\text { systems thinking } \\
\text { - Founding of the US } \\
\text { foresight tradition } \\
\text { around the works of } \\
\text { Hermann Kahn and the } \\
\text { RAND corporation, } \\
\text { centered around future } \\
\text { anticipation methods, } \\
\text { such as the Delphi } \\
\text { technique }\end{array}$ & $\begin{array}{l}\text { - First success in } 1970 \text { s, } \\
\text { when Shell anticipated } \\
\text { the possibility of an oil } \\
\text { crisis } \\
\text { - Diffusion of the scenario } \\
\text { technique to other } \\
\text { companies } \\
\text { - Scenario analysis is } \\
\text { established as the key } \\
\text { foresight technique that } \\
\text { emphasized the } \\
\text { importance of systems } \\
\text { thinking }\end{array}$ & $\begin{array}{l}\text { - Growing usage of } \\
\text { corporate foresight } \\
\text { techniques (i.e. Philips, } \\
\text { Nokia, Siemens, } \\
\text { Daimler) } \\
\text { - Adoption of the road- } \\
\text { mapping technique as a } \\
\text { tool to plan towards a } \\
\text { probable or desired } \\
\text { future } \\
\text { - Only few examples } \\
\text { where Corporate Fore- } \\
\text { sight is implemented } \\
\text { systematically }\end{array}$ & $\begin{array}{l}\text { - Corporate foresight } \\
\text { methods are well } \\
\text { understood in } \\
\text { application and impact } \\
\text { - Need for integration of } \\
\text { foresight in existing } \\
\text { processes and } \\
\text { managerial systems } \\
\text { - Emergence of } \\
\text { Corporate Foresight as } \\
\text { an integrated practice } \\
\text { that increases strategic } \\
\text { responsiveness and } \\
\text { enhances the innovation } \\
\text { capacity }\end{array}$ \\
\hline
\end{tabular}

Figure 1 - Development of the Corporate Foresight research stream (Adapted from Rohrbeck et al., 2015)

\section{Foresight and strategy development}

Foresight is one of the common and useful tools in strategy development (Andersen and Borup, 2009; Darkow, 2015; Reger, 2001; Heiko et al., 2010). Foresight is closely related to strategy-setting and strategy planning (Will, 2008; Berkhout and Hertin, 2002). Andersen and Borup (2009) believe foresight exercises can enhance strategy development. A foresight-based approach helps companies use their managers' potential more effectively in strategy development (Darkow, 2015). According to a conceptual framework of technology foresight, foresight is a critical element in strategy creation process (Reger, 2001). Ruff (2006) mentioned that corporate 
foresight provides companies with analysis of long-term visions that may be used in corporate strategies and innovation. Researchers suggested that foresight as a futures orientation of an organization can be considered as a part of strategic management (Heiko et al., 2010). Corporate foresight can be employed both in strategic planning and strategic implementation (Pirttimäki, 2006).

\section{Foresight and decision-making}

Foresight also plays a very significant role in the decision-making process (Berkhout and Hertin, 2002; Cook et al., 2014; Vecchiato, 2012). Berkhout and Hertin (2002) explained that "the ultimate aim of futures studies is to explore future trends and potential discontinuities to inform decision-making" (p. 39). They believe foresight (i.e., thinking about the future) is fundamental to decision-making and without that making decision is impossible. Foresight is an important tool in the decision-making process as it prepares managers to deal with environmental uncertainty and complexity, so they can handle future events properly (Vecchiato, 2012). Strategic foresight by offering diverse toolkit which enables decision-makers to be aware of early warnings, aid managers in thinking creatively and making decisions that result in a more desirable future (Cook

et al., 2014). Researchers state that strategic foresight increases a company's awareness of the environment which leads to making more robust decision to future changes (Heger and Rohrbeck, 2012). Cook et al. (2014) indicated that foresight enhances environmental decision-making process in different ways including monitoring existing problems, identifying emerging threats and opportunities, evaluating the dependence of policy, and defining a research agenda. Foresight activities enable companies to manage organizational issues and implement related decisions effectively (Rohrbeck et al., 2015). 


\section{Foresight and policy-making}

Many studies have discussed the linkage of foresight and policy (Hilbert et al., 2009; Habegger, 2010; Da Costa and et al., 2011; Havas et al., 2010). According to a study, instrumental outcomes of foresight activities have a positive impact on policy-making process and development of related actions (Könnölä et al., 2011). A review of foresight activities in three countries shows that strategic foresight contributes to public policy-making (Habegger, 2010). According to this review, foresight provides more systematic knowledge about environmental trends and developments for policy-makers. Havas et al. (2010) specified that foresight in has three main functions policy-making process such as policy-informing, policy counseling, and policy facilitating. Also, Da Costa and et al. (2011) introduced six functions of foresight for policymaking including informing policy, facilitating policy implementation, embedding participation in policy-making, supporting policy definition, reconfiguring the policy system, and symbolic function. According to a study conducted in developing countries, foresight exercises can make policy-making more participatory and also public decision-making more transparent and accountable (Hilbert et al., 2009).

\section{Foresight and innovation}

Many researchers have highlighted the contribution of foresight to innovation (Heiko et al., 2010; Rohrbeck and Gemünden, 2011; Georghiou and Harper, 2011). Andriopoulos and Gotsi (2006) believe that foresight as a perpetual future probing and organizational learning process that is critical for sustaining successful multiple product innovation. Corporate foresight improves innovation process in two ways; it helps to discover or create new ideas by providing insight about future environmental changes and helps to evaluate the commercial and technological viability of the ideas (Heiko et al., 2010). Based on empirical evidence, corporate foresight helps a company 
improve its innovation capability in three ways: 1) Identification of new business opportunities, 2) providing more innovative ideas, and 3) challenging projects in order to improve their quality and originality (Rohrbeck and Gemünden, 2011). Scholars also suggested that foresight can support innovation policy in four different modes: as a systematic instrument fostering innovation capability, as an orientation toward social needs, as an agenda-setting process, and as a provider of anticipatory intelligence for decision-making (Warnke and Heimeriks, 2008). Georghiou and Harper (2011) stated that foresight is a useful tool in designing and implementing innovation policies. They mentioned that foresight plays three major roles including corrective, disruptive and creative roles.

\section{Foresight and opportunity recognition}

The relation between foresight and opportunity recognition has been mentioned in some studies (Major et al., 2001; Berkhout and Hertin, 2002; Vecchiato, 2012; Havas et al., 2010). Foresight enables decision-makers to explore and assess business opportunities and possible upcoming issues (Cohen and Levinthal, 1990; Rappert, 1999). Berkhout and Hertin (2002) defined foresight as a "way of thinking about the future, of identifying opportunities and threats that may arise over the coming years and decades" (P. 36). Foresight as a learning process assists individuals to see future opportunities and threats before they appear in the environment (Vecchiato, 2012). Havas et al. (2010) mentioned that foresight offers different opportunities that can be used to shape the desirable future. Foresight activities raise the level of alertness to future risks and opportunities and prepare us to meet them (Warnke and Heimeriks, 2008; Cuhls, 2003). Andersen and Borup (2009) believe one of the goals for foresight is "exploring future opportunities so that priorities for investment in science and innovation activities" (p. 919). Researchers explained that exploration 
and exploitation of new opportunities is both a result of successful implementation of foresight (Major et al., 2001).

\section{Foresight methods}

Researchers introduced and discussed several foresight methods in their studies (Popper, 2008b; Pinter, 2013; Porter, 2010). There is no single best foresight method because the selection of a method depends on function and context of foresight (Slaughter, 2004; Magruk, 2015; Porter, 2010). Generally, foresight methods can be chosen based on fundamental attributes and fundamental elements (Popper, 2008b). The former refers to nature methods (i.e., quantitative and qualitative) and capabilities of methods (i.e., ability to collect and process). The fundamental elements refer to factors and conditions that impact the process of foresight (e.g. industry, stakeholders, time scale, etc.). According to researchers, the most popular and used foresight methods are trend and market analysis, scenarios, Delphi technique, road-mapping, environmental scanning, and simulations. (Pinter, 2013; Will, 2008). According to another study that used data collected from 886 cases of foresight practice (Figure 2), the most commonly used foresight methods were literature review, expert panels, and scenarios (Popper, 2008b). 


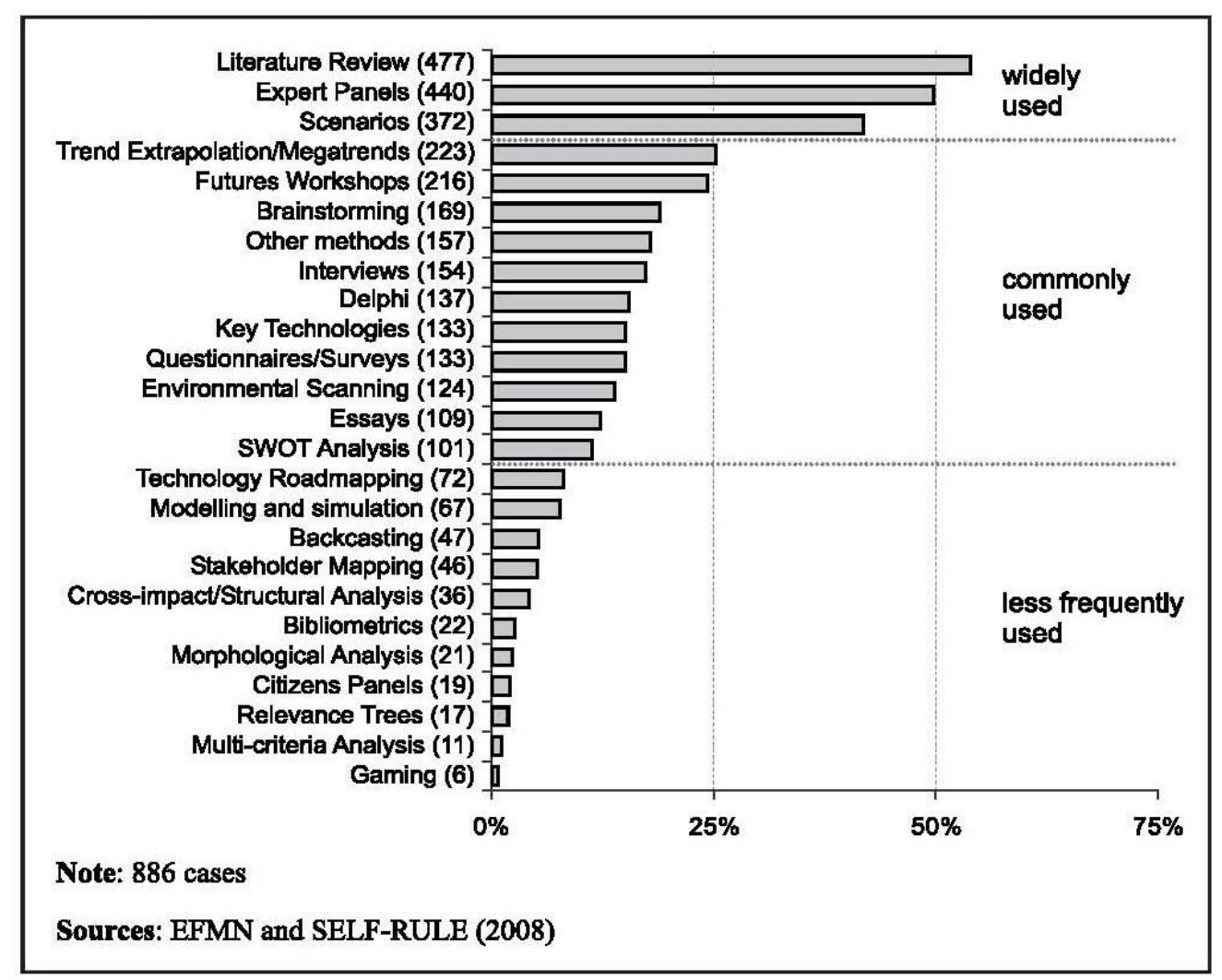

Figure 2 - Foresight Methods - (adapted from Popper, 2008b)

\section{Scenarios and foresight}

Scenarios are one the most common and useful methods of foresight (Heger and Rohrbeck, 2012; Vecchiato, 2012; Major et al., 2001). Scenarios play a vital role in examinations of the future and understanding how a possible future may progress (Pillkahn, 2008; Burt et al., 2006). Bishop et al. (2007) asserted that scenarios are associated with futurology for two reasons: 1) it enables to think deeply and creatively about the future and manage the risk of being unprepared;2) it helps to consider several plausible futures and be prepared for uncertainties. Researchers believe that scenarios as a heuristic tool for foresight allow organizations to visualize likely futures and consider desirable ones (Berkhout and Hertin, 2002; Tsoukas and Shepherd, 2004; Popper, 2008b, Rohrbeck et al., 2015; Andriopoulos and Gotsi, 2006). Berkhout and Hertin (2002) mentioned that 
scenario exercises not only provide pictures of the far future but assess environmental issues and changes. Scenarios are credible and coherent stories describing different ways that lead to possible futures (Vecchiato, 2012) .Burt et al. (2006) posited that scenario planning assists managers in analyzing and understanding environmental changes. Scenario planning enables people to think creatively and observe unforeseen futures by encouraging exploration of the way that uncertainty in trends and changes result in various futures (Cook et al., 2014; Darkow, 2015). In fact, scenario development is a tool that is used to increase the knowledge about the future in order to handle and lower the level of uncertainty. (Könnölä et al., 2011; Rappert, 1999). Godet and Roubelat (1996) pointed out that organizations should use scenario methods to anticipate the future proactively.

\section{Scenarios and opportunity recognition}

The relation between scenarios and opportunity recognition has been mentioned in few studies. Lindgren and Bandhold (2003) explained that scenario techniques can help to reduce uncertainty and complexity of the future business environment and unfold it in order to discover potential, contextual opportunities. Scenarios could have seeds of new business opportunities (Schoemaker, 1995). Cook et al. (2014) believe scenario planning is a tool to create different visions of the future which can result in new perspectives. Researchers suggested that scenario development provides detailed and creative information that illustrates key opportunities and threats (Cook et al., 2014; Darkow, 2015). Also, Darkow (2015) stated that scenario results could be used for producing innovation. Scenario analysis is one of the methods that aid in exploring a new business field (Berkhout and Hertin, 2002). Passey et al. (2006) showed that scenario building is an important tool to improve innovation and recognize emerging markets leading to business opportunities. 


\section{Scenario development}

"The main purpose of developing scenarios is to stimulate thinking about possible occurrences, assumptions relating these occurrences, possible opportunities and risks, and courses of action" (Jarke et al., 1998, P. 156). Generally, there are two types of scenarios: exploratory scenarios (i.e., using past and current trends to create scenarios showing plausible futures), and anticipatory scenarios (i.e., scenarios that describe how desirable futures can emerge) (Godet and Roubelat, 1996). Wilkinson and Eidinow (2008) proposed a typology that introduces three types of scenarios such as problem-focused scenarios, actor-focused scenarios, and reflexive interventionist (multi-agent-based) scenarios. Berkhout and Hertin (2002) pointed out three main steps that should be considered in scenario creation: 1) identification of central variables, 2) analysis of actors' role and strategies, 3) creation of possible scenarios based on the prior steps. According to Burt at el. (2006), the process of scenario planning has different steps such as identifying areas of concern, brainstorming for key uncertainties, clustering the uncertainties, prioritizing them, developing scenarios and so on. Bishop et al. (2007) in their study classified scenario techniques into eight categories and discussed inputs, processes, and outputs of each one. Foster (1993) offered a scenario writing framework for small business that includes identification of relevant key factors, key assumptions, information sources, key issues, and creating pictures of the future.

The previous studies indicated that the process of opportunity recognition can be affected by varieties of factors including prior knowledge, entrepreneurial alertness, creativity, entrepreneurial learning, social network, and environmental changes. Overlooking the future as an origin of opportunities in these studies, led to ignorance of the potential role of future-related elements like foresight. According to the literature review, although some of the research on 
foresight mentioned that foresight could be helpful in identification of opportunities, they have not thoroughly studied its role in opportunity recognition. According to the review, most of the researchers have regarded foresight as a capability that helps the companies to deal with uncertainties and future threats. They have mainly discussed its contribution to strategy development, decision-making, policy-making, and innovation. So, the absence of an opportunityoriented perspective on foresight that underlines the need for identifying future opportunities is noticeable. This research is aimed to study the role of foresight in the entrepreneurial opportunity recognition phase. Besides, according to the literature review, one of the key foresight methods which also is associated with opportunity recognition is scenario development/thinking. Thus, in order to gain a better understanding of foresight role in opportunity recognition, scenario development is examined particularly. 


\section{METHODOLOGY}

Due to the research objectives and questions, a qualitative method has been selected. Since the study is aimed to use primary data in order to generate new knowledge (i.e., a pattern or framework), an inductive approach has been employed. Thomas (2006) proposes the general inductive approach that provides a systematic procedure for evaluators who seek a straightforward and nontechnical way to conduct qualitative analyses. He believes this approach can be used for three purposes including condensing raw textual data to a summary format, establishing links between the research objectives and the summary, and developing a framework of the underlying structure of experiences or processes.

\section{Data}

The target population for this study is opportunity seekers. They are individuals who have already identified entrepreneurial opportunities or have been searching for one. The reason for considering the criteria is to hear from people who have been involved in opportunity identification and realize whether and how they used foresight in this process. This population includes:

- $\quad$ Entrepreneurs (who have founded a business)

- $\quad$ People who have identified a business opportunity and are working on it to establish a startup

- $\quad$ People who are looking for a business opportunity

In this study, a purposeful sampling technique has been applied and the sample size has determined based on theoretical saturation, so sampling continued until no new information emerged in the data (Palinkas, 2015; Francis et al., 2010). The sixteen participants of this study have been recruited from two sources: (1) business incubators, and (2) the researcher's social networks and personal contacts. Business incubators as an important community of entrepreneurs 
have been reached to employee start-up founders or innovators who have already identified a business idea and are working on it. All of the recruited participants from this source were from Ryerson University's business incubators (called zones). The researcher's network was specifically utilized to improve the diversity of the research sample by employing other eligible participants like established business owners and individuals who actively look for entrepreneurial opportunities in different areas. The sample of 16 participants included social entrepreneurs, hightech entrepreneurs, service entrepreneurs, businesspersons, managers, scientists, academic entrepreneurs, and students.

Regarding the data gathering procedure, a semi-structured interview has been used to gather qualitative data from the participants. The average length of the interview was about 20 minutes and the interviews have been audio recorded. In accordance with the interview type, an interview guide containing four key questions and some sub-questions (varying based on participants answers) has been covered during the interviews (see Appendix A for interview questions).

\section{Data analysis}

Thematic analysis method as one of the most useful qualitative data analysis methods has been applied. First, this method is totally coherent with the general inductive approach described earlier. Secondly, the thematic analysis is very consistent with the research objectives. King (2004) claims that thematic analysis is a useful means for investigating different perspectives of participants and summarizing key features (i.e., similarities and differences). Finally, this method

provides a highly flexible approach which is not closely tied to specific theories (Nowell et al., 2017). In accordance with Braun and Clarke (2006) and Thomas (2006), the analysis process is as follows: 
1. Exploring data: transcribing the audio recordings, initial readings of the text data, and re-reading and taking notes.

2. Generating initial codes: identifying specific text segments related to the objectives

3. Generating themes: searching for themes by relating codes, and organizing them into potential themes

4. Reviewing and defining themes: refining themes in term of consistency between themes and supporting codes, assessing whether the themes represent the data set as a whole, and defining and labeling the themes

5. Creating a pattern or framework: synthesizing final themes and searching for potential correlations among them (i.e., producing thematic map)

\section{Trustworthiness}

Since we cannot use the typical quantitative tests with established metrics about validity and reliability in qualitative research, "trustworthiness" is more appropriate context to use in this study. In order to ensure the trustworthiness of the research, Guba's framework (1981) has been considered which contains four major criteria such as credibility, transferability, dependability, and confirmability. Credibility refers to the believability and accuracy of the findings. In addressing credibility, investigators attempt to explain "how we ensure rigor in the research process and how we communicate to others that we have done so" (Gasson, 2004, p. 95). Transferability is concerned with the degree that the findings can be applied to other situations or populations. Dependability refers to the consistency of findings across time, researchers, and analysis methods (Gasson, 2004). Finally, confirmability relates to objectivity. In addressing objectivity, researchers try to confirm that the findings are the result of the actual data, rather than their preferences. Among the several different strategies that have been proposed to improve the 
trustworthiness of research, two main methods including thick description and peer debriefing are used in this study (Krefting, 1991; Shenton, 2004).

Thick description, by delivering thorough descriptions about different aspects and phases of research, enables readers to evaluate its trustworthiness. (Krefting, 1991; Shenton, 2004). This method supports transferability, dependability, and confirmability of study. Hence, the researcher has attempted to provide readers with detailed and rich descriptions of the research context, the constructs, the participants and data collection process, analysis procedure, and findings.

Peer debriefing is another method for improving trustworthiness and conducting a research audit (Krefting, 1991; Shenton, 2004). This method mostly helps to shore up the credibility, dependability, and confirmability of research. In this technique, a disinterested peer assists the researcher during the data analysis and coding process so that she/he will be able to uncover and avoid possible bias (i.e., taken for granted perspective and assumptions).

In this research, the peer debriefing task has been performed in two levels of analysis with the assistance of a scholar who has experience with qualitative research. In the first level, the peer was given the research objectives and a quarter of transcribed data to generate a second set of themes. Then, the set of themes (consisting of five themes) have been compared with the initial set (consisting of six themes) created from the same data segment by the researcher in order to evaluate the extent of overlap. The comparison showed that four of the themes from the second set were very similar to the initial ones. In the second phase of the peer debriefing process, called check on the clarity of themes (Thomas, 2006), the peer was given another portion (15\%) of transcribed data and the extracted themes along with their definitions and asked to assign the sections of the raw text to the available themes. According to the results, he could identify and 
relate 0.78 of text segments that were identified previously by the researcher. Finally, both researchers discussed and resolved the discrepancies to enhance the trustworthiness of results.

It should also be mentioned that the whole research process has been conducted under the supervision of the thesis supervisor who has continually evaluated each phase, challenged the researcher, and provided additional, sometimes alternative, perspectives on methodology and analysis processes. Shenton (2004) named this provision "frequent debriefing sessions" that happens between the researcher and his/her superiors. 


\section{RESULTS}

In this section, first, the researcher has demonstrated the results obtained from analyzing the data about whether the participants are future-oriented in opportunity recognition. Secondly, the results of analyzing the data regarding why and how they explore the future to identify entrepreneurial opportunities have been indicated by explaining the emergent themes and citing the data.

\section{Future-orientation in entrepreneurial opportunity recognition}

According to the findings, the majority of participants (11 out of 16) stated that they tend to be future-oriented when they are looking for entrepreneurial opportunities. But, a couple of them defined themselves as present-oriented persons and three of them answered that they do not have any tendency in this regard. It should be mentioned that almost all of the participants underlined that they typically consider both the current environment and the future during opportunity recognition. In the below quotations, participants describe the future-orientation in opportunity recognition:

Participant 1 said:

It's like anticipating opportunities and being positioned to take advantage of those opportunities. This is what startups do.

Participant 15 said:

I was looking at it from a futuristic perspective. I was trying to predict what market might want in the future. Given my interest and the industries I'm involved in, they do tend to be fairly, technically advanced disruptive types of technologies. So, it always requires some level of trying to imagine future state. 


\section{Themes}

Four major themes have been identified in the data set (Figure 3). These themes have been recognized base on their significance (i.e., relation to the research objectives) and prevalence. The same criteria have been applied to the important components of the themes (i.e., major codes). The components have been used for explaining the themes. Also, some representative quotations from the participants have been included for supporting the themes and components.

\section{Purposes}

The participants mentioned three main reasons for applying foresight in opportunity recognition. First, some of them mentioned that future opportunities are more sustainable in general.

Participant 4 said:

Because you need to be able to have some sort of insight or hypothesis, like we do about what we're going into. You don't plan of a business to exist for a year. You plan a business to exist for tens of years and generations if you're really trying to be something big.

Participant 5 said:

So, what is going to happen in ten years from now? And so, I'm not going to create a product today that is not going to have ramification in the future. I'm going to create a product that it going to fit resoundingly well as a future appliance, as a solution for the future that people will use. So, I'm basically calling it fridge or microwave of the future.

Secondly, the data shows that limitation of time and/or resources is another important reason that encourages the participants to apply foresight in opportunity recognition. 


\section{Participant 8 said:}

Because it's going to take time to develop the product. It's going to take time to create the demand for it. So, if there's a huge demand now, in most cases the product is going to have a short life span. If the demand is not as great now but you see that there is a desire for it, you're going to get a better demand down the road for it.

Participant 14 said:

Because I'm a student and my resources are limited.

Thirdly, some of the participants described that future opportunities are less competitive than current opportunities.

Participant 9 said:

I think the better opportunities are ones that probably are looking into the future both because I mean sustainability is very important but also it probably presents a better competitive situation. If there is something that's going to make it more feasible in the future as opposed to something that is currently feasible or current opportunity because everybody's going to be at it then.

Participant 13 said:

Because current ones, everybody can do it, everybody copies what you're doing, and they try to get back to what you're doing, and I obviously want to be one step ahead.

Participant 16 said:

Because I think the opportunities exist in the present, will be ones that everybody can see. So, probably everybody else is chasing them and there is going to be too 
many competitors doing that. I find an opportunity that doesn't exist yet, so I can get ready for it.

In addition to the three main reasons, data shows that some participants believe that foresight helps them estimate market demand, and evaluate and validate current opportunities.

Participant 9 said:

The other important thing is the market. The market for this particular product is growing because of the demographics of the population is something that will be in demand for people over the age of 50 or something like that and the number of people that are reaching that age, and so the demand is something that's going to grow in the future, too.

Participant 15 said:

It [scenario development] helps me determine in a lot of cases whether it is actually a problem that is worth solving, and a problem that is worth thinking about further or taking more deliberate actions.

According to the data analysis, participants also apply foresight for purposes other than opportunity recognition. Some of the participants explained that they apply foresight for in order to manage risk (e.g. preparing for future changes and adapting accordingly and creating plan B).

Participant 8 said:

You need to plan on how to bring a product to market, so you need to understand if something happens along the way. If you are not able to react to it then there is going to be issues.

Participant 4 said: 
We're probably more on the side of forward-thinking just because we know that we have to make changes in the industry of the charitable sector in order to get to where we believe we're going to be.

Participant 2 said:

Current opportunities are never guaranteed...basically, looking for future opportunities is kind of like insurance. You have something to sort of fall back on based on the current situation because something is outside of our control as business owners.

Also, participants suggested that they apply foresight for financial purposes to forecast possible costs, revenues, etc.

Participant 8 said:

I would have to determine, depending on what the product is, what it is going to cost me to bring it to market, see what I'm either going to replace or add into the future and base on potential numbers that I could generate through sales and a lot of it is a guess.

Participant 11 said:

One thing we did too [during writing the business plan], we had a baseline [financial] forecast, we had optimistic and a pessimistic. So, when you are working on that level of detail you tend to run those scenario analyses, I call them sensitivity analysis [a financial technique].

\section{Inputs}

Inputs is another considerable theme in the data which refers to information, insight, and awareness about the future. Based on the data analysis, trends and developments is the most 
common and significant source that aids the participants in foresight process. This source includes the trends and changes in macroenvironmental factors such as culture, technology, and demographics, and in market. Below are some quotations demonstrating the importance of trends and developments:

Participant 1 said:

Things are moving very quickly in the world of technology especially mobile devices and wearables, and cultural shifts in terms of how people engage with technology and how they think about health and wellness, and then these large macro shifts in healthcare. So, there are all these forces at play, a lot of macros.

Participant 5 said:

It's actually a bit of both [present and the future] because you're looking at the current environment and the trends today and where those trends are going to end up in the future. So, I had to consider the trending of in my particular example food and food sourcing, and the result of where the current trend is leading us where the current technology is leading us versus where I would prefer it to go.

Participant 6 said:

I try to know what trends are happening, so I can extrapolate them and imagine if this keeps happening what would the world look like in the future Participant 9 said:

You can get a bunch of projections, you can follow trends, you can look at data that suggests growth in any number of areas in the technology, in the demand and all the rest of it but yeah in the back of my mind I'm thinking about something could change that will affect the markets or the demand and that kind of things. 
Some of the participants pointed out that viewpoints and works of other people and companies inspire them in term of foresight.

Participant 3 said:

You are having people around you who seeking out opinions, thought leader, influencers or whoever they are, they have different views, so the biggest kind of growth happens where because sometimes it's hard to see outside of your sphere of influence. So, it pushes you when you go look for people who have different views of the world than you do... and also part of it is to see what are people working on, what are some big companies are focused on and look out of your own sphere and how certain trends are happening, or you might want to look what geopolitical situations are happening.

Participant 12 said:

I try to follow all the big companies like Google, Apple, Tesla, and Samsung. Every year they have at least one to two conferences that what they're doing, what do you want to become, where do they see the future is happening and you get to learn and see if you're able to pick up some pieces together.

In addition, a few participants indicated their prior experience and knowledge as helpful sources of foresight.

Participant 4 said:

For us a lot of it is based on our own experiences and or research we've been involved in the sector, I personally been involved in the sector for 8 plus years now and so I've got a lot of experience as to where it was and where it's been going, and being able to see the trends. 


\section{Actions}

One of the important themes that emerged from the interview data is the actions. This theme refers to actions implemented by the participants during foresight for opportunity recognition. The two most widely mentioned actions are networking and research. Firstly, networking basically includes talking to people and attending events.

Participant 2 said:

My number one thing is talking to people. So, I talk to people in the relevant fields and then we'll have a conversation about the future because sometimes my view of the future is different than someone else's. Although I always try to engage someone a little bit more involved than me someone smarter than I am, someone that has more experience... And that is like repeatable. I do that with everyone. I just start talking and try to make connections.

Participant 13 said:

Yes, I get involved with people, I get involved in the associations. I joined a group of people in the states that actually was pretty costly for me in the beginning but not only I attended the conference's in which point you from the exhibitors so you can see exactly what the industry is doing, what's the trend, what's new what's not.

Participant 14 said:

The best way is to go around and discussing these things with people. If you go to that networking event or like if you know someone who's in the industry, if you bring these topics up and you see their reaction that I get feedback on them you can get a better idea that okay so maybe this will actually happen... Ryerson has been bringing in speakers and industry expert from outside so they're continuously 
coming in and I actually attend $80 \%$ of them and I attended a lot of these events and then I do my own little research like some Google search.

Secondly, the research includes doing general research like reading articles and magazines, following news sources, and also conducting primary and secondary market research.

Participant 4 said:

A ton of research in terms of just reading and really enveloping ourselves within the topic of what we're trying to solve to make sure that we're kind of following along the same path and with that and like simple tactical things like I've got a Google alert for social impact... and now I receive an alert once a day with 10 to 15 articles and...so a lot of it is simply just research a lot of customer discovery and discussions within that

Participant 11 said:

Being relatively well read and reading the right stuff, so you know I read The Economist and The Global and Mail. I don't read the New York Times but I go, and I look at their app and I see the headlines and the top highlights and over time you pick up on things.

Participant 5 said:

I talked to a lot of people. I'm in food production technology and I noticed that there is a lot of technology being thrown at food production technology in urban settings and as I started looking into that and I started researching more about that I noticed a trend there...Yeah, it's anecdotal plus research in trends whether it's scientific papers whether it's talking to experts. 
Furthermore, connecting dots to create patterns and visualizing different futures (i.e., scenario thinking) are the other actions that some participants claimed they do during foresight.

Participant 3 said:

What happens is that because you're open, you might notice an inefficiency one day an opportunity another and then you start seeing a trend or you can start connecting dots... another time you start seeing things are patterned and pre-indicator to things that could happen in the future...You as the entrepreneur, as the person that's trying to innovate have to be able to discern which ones of those pieces of information are getting, try to piece them together and then it's almost go back either to those people or somebody that has a different point of view to see if you're connecting the dots in the right way.

Participant 4 said:

So, ultimately you are making hypotheses about where you believe it's going to go...We had a kind of baseline hypothesis but within that, there're different fractions that could change.

Participant 5 said:

I Envision the future based on the current trends of urbanization... The vision I'm seeing is that taller living apartments and dwellings coming up, so these urban settings are showing up...I mean it's almost like watching Star Wars, you know, you're watching a movie and it is your mind, you're playing this movie and it's very visual for me...I Envision a city of the future the trends with Amazon and Google are smart cities and you're hearing a lot about cities and then I think about smart cities and the term appliance is very purposeful. I'm using that term purposely 
because I envision a new appliance entering into the realm of a person's condo or home.

\section{Methods}

The methods used by participants is another important theme that appeared from the interview data. This theme refers to the specific tools and techniques that are used in foresight. According to the analyses, one of the considerable foresight methods is scenario thinking which appeared even in the data gathered before asking the last interview question about the scenario development. In most of the cases concerned with scenario thinking, the participants did not name the exact term (i.e., scenarios), but the course of actions they described was clearly consistent with the method. Also, results show that the majority of participants are not very familiar with the term itself. The following quotations from interview data demonstrate the methods.

Participant 10 said:

I tried to think if that industry is about to be disrupted by anything that you can imagine for instance in my case I tried to think about the crazy things...Another thing is to think how the competitive market will behave after you start your new business so again the concern about the barriers that would protect my idea from competitors... do you have some kind of mechanisms that would prevent them from

copying it... but I had this personal rule of planting with pessimism and harvesting with optimism so I always try to consider let's say at least three scenarios pessimistic, realistic and optimistic scenarios.

Participant 15 said: 
So, my visualization of the future usually is almost like a use case. Like what customers or industries or companies are actually doing related to the problem area, right now, and how that could change in a bunch different way in the future.

Participant 11 said:

I don't know how you would be considering out business opportunities and not thinking through scenarios. I think it would happen as a natural part of the process of thinking through entrepreneurial opportunities, you know, part of it is what are the consequences.

Participant 5 said:

When I think about smart cities and the term appliance is very purposeful. I'm using that term purposely because I envision a new appliance entering into the realm of a person's condo or home that they won't ask for so when you purchase a condo the fridge and the microwave are already there and I want my appliance to be already there, and I don't visualize my appliance like somebody just placed it there I visualize my appliance that they built it into the condo as part of the building as part of the building.

The other common methods that some of the participants pointed out are methods such as using a whiteboard, use cases, business model canvas. Here are some participants quotations indicating the usage of methods:

Participant 2 said:

We do storyboard. We draw an ideal timeline on a whiteboard. We write down our opportunities on the top of the board and then we start to place the opportunities on the timeline... We also do branches. In case one of them goes sour. 
Participant 3 said:

So, what I do is I whiteboard [use whiteboard] a lot of things because I am a very visual person. So, for me, visualization helps me quite a bit...and writing down whether like use cases or diagrams helps to put things into practice and see the possible gaps.

Said participant 4:

One thing that we found to be really helpful is like a business model canvas so instead of writing a business plan being able to kind of one page state really what is your future vision for something, what are all the components related to that...there's some visualization in that in terms of we believe this let's do the research around that plot that out and see it from a holistic perspective and then make the shifts and changes based on what we believe needs to happen over a period of time.

Participant 5 said:

I call them use cases. For instance, of gardener today, it's a target market for us so a gardener today who gardens for food gardens typically outside and sometimes indoors but it's inefficient indoors but outside it doesn't work because you cannot do it in If you experience an extreme climate, you can't do it. So, then what I do is I say okay well with my product this person who's doing this existing scenario is going to do this in the future and she won't garden outside but she'll garden inside in my own tiny farm like in this way. 


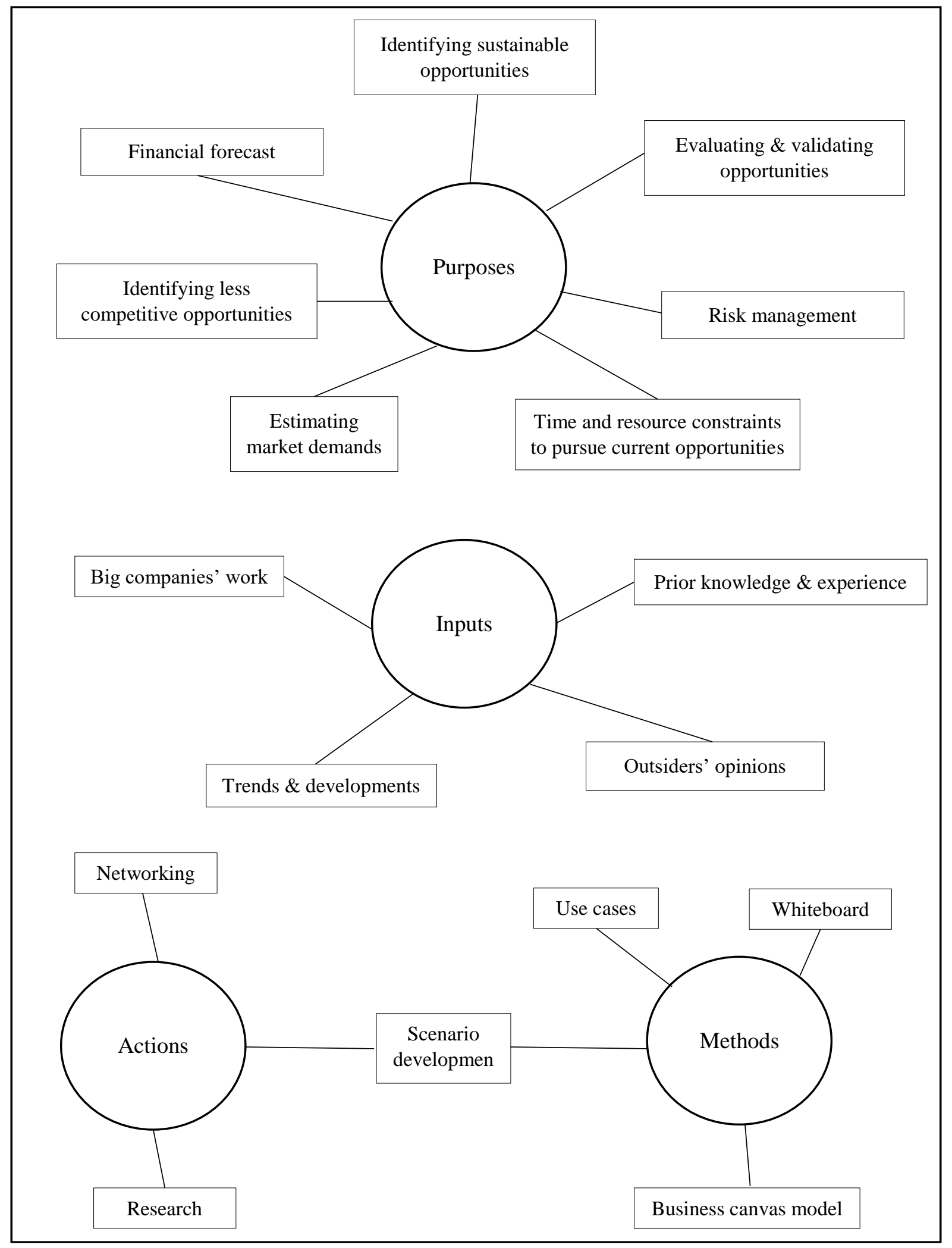

Figure 3 - Final thematic map 


\section{DISCUSSION}

This research for the first time exposed the overlooked importance of the future (as a source of opportunities) and foresight (i.e., capability of exploring the future) in entrepreneurial opportunity recognition. Not only this gap is emergent in the opportunity recognition literature, but it is evident in the foresight literature. Most of the research on foresight have considered it as a corporate capability which is mainly concerned with future uncertainty. With the uncertaintyoriented perspective, the primary purpose of foresight is dealing with future threats. However, this research with an opportunity-oriented perspective on foresight studied its role in entrepreneurial opportunity recognition. The main purpose of this research was twofold. First, it investigated whether and why the opportunity seekers are future-oriented in entrepreneurial opportunity recognition. Then, it studied how they explore the future (i.e., applying foresight) to identify entrepreneurial opportunities. In order to achieve the objectives, qualitative data was gathered and analyzed for reporting emergent themes and relationships among them.

According to the results, while the majority of opportunity seekers at first emphasized that they explore both current and future environments to identify entrepreneurial opportunities, they reported that they have more tendency toward the future. This implies that the individuals apply foresight in process of opportunity recognition.

The different purposes mentioned for the future-orientation can be categorized into two main groups. The first group of purposes is related to opportunity recognition, which is the primary focus of this research, and exposes why the opportunity seekers apply foresight in opportunity recognition. These purposes include identifying more sustainable opportunities, identify less competitive opportunities, estimating market demands, and evaluating and validating opportunities. The first purpose approves that sustainability and longevity of visions on the future 
are very essential elements in foresight (Schwarz, 1991; Will, 2008). Also, regarding the last purpose, researchers stated that foresight helps evaluate the commercial and technological viability of the ideas (Heiko et al., 2010). Moreover, the limitation of time and/or resources for exploiting the current opportunities was a major reason for considering future opportunities. The findings confirm the role of foresight in opportunity recognition. Some of the previous studies also suggested foresight could assist firms in detecting future opportunities (Major et al., 2001; Vecchiato, 2012; Havas et al., 2010).

The second group is the purposes are related to strategic reasons such as financial forecast and risk management (e.g. as preparation for future changes and creating plan B). Most of the previous research on foresight, which studied it in corporate level, highlighted its role mainly in strategic processes such as strategy development, policy-making, decision-making and so on (Darkow, 2015; Hilbert et al., 2009; Berkhout and Hertin, 2002). One of the key tasks in foresight is risk management. Scholars emphasized that a large portion of corporate foresight is dealing with uncertainty and dynamic of the future and this would happen mostly by identifying changes and proactively preparing the organization for them (Rohrbeck et al., 2015; Heiko et al., 2010; Vecchiato, 2012). Thus, the findings suggesting applying foresight for strategic purposes are consistent with the discussions of previous research.

\section{Entrepreneurial foresight}

Regarding how the opportunity seekers explore the future (i.e., applying foresight) to spot potential future opportunities, three significant themes that include inputs, actions, and methods were identified in the data set.

Inputs refer to the data and information that the individuals utilized to gain some idea and insight about the future. The most important input in the data set was trends and developments. 
This includes the trends and changes that lead the opportunity seekers to the future and allow them to gain some vision about the future. According to the results, trends and changes in macroenvironmental factors such as technology, economy, culture and demographics, and market trends were the major ones. This finding is consistent with the discussions and results from other studies that highlighted the significance of trends and development foresight (Ruff, 2006; Habegger, 2010) and in opportunity recognition (Baron, 2006; Eckhardt and Shane, 2003).

Another input was the viewpoints and works of other people and companies. First, the participants believed that it is important to leave their comfort zone and be open to distinct ideas to be able to see beyond the current situation. Secondly, they assumed that since some of the entities like business magnates and large companies are highly engaged, visionary, and capable, their works and accomplishments would be inspiring and helpful in foreseeing future opportunities.

In addition, prior knowledge and experience of the opportunity seekers were considerable inputs that initiated and facilitated applying foresight in opportunity recognition. This finding would be consistent with the finding from studies that suggested the role of prior knowledge and experience in opportunity recognition (Marvel and Lumpkin, 2007; Hajizadeh and Zali, 2016). This input also can affect perceiving the other inputs, because people often search out information that is related to their previous experience and knowledge. Researchers stated that individuals' interpretative frameworks and schemata are influenced by their prior experience and knowledge (Tang, 2009; Valliere 2011, 2013). So, this input can impact opportunity seekers ability in searching and associating new information (e.g., external changes, future trends, and outsiders' opinion). 
Actions refer to the provisions that were implemented during foresight for opportunity recognition. The results show that the most commonly mentioned actions were networking (e.g. talking to people and attending events) and research (e.g. reading articles and magazines, following news sources, and doing market research). In foresight, as a learning process (Vecchiato, 2012), both networking and doing research could provide individuals with the foresight inputs. Researchers also stated that foresight increases the level of alertness and sensitivity to environmental trends and signals (Battistella, 2014; Heger and Rohrbeck, 2012). This could justify the identified actions.

Visualizing different futures (i.e., scenario thinking) and connecting dots were two other important actions among the participants. These two actions are highly related to each other in term procedure and outcome. According to the results, connecting dots refers to act of collecting information and creating patterns that can result in scenarios. Thus, it could be considered as a subprocess of scenario thinking/development, which is explained further below.

Methods refer to the specific tools and techniques that were used in foresight process. These methods aided the opportunity seekers in identifying future opportunities. The most important method was scenario development. Scenarios are different likely futures that enabled the participants to think deeply and creatively about the future and identify potential opportunities (Bishop et al., 2007). Some of the previous studies suggested the role of scenarios in opportunity recognition, as well. (Cook et al., 2014; Darkow, 2015; Passey et al., 2006). As was mentioned in the results section, in most of the cases the participants did not name the exact term. The researcher believes it could be due to two reasons. First, the answers to the last interview question, which was about scenarios, showed that many of participants were not familiar with the term itself or its 
accurate definition. Second, they probably were not fully aware that they use this method (i.e., considering different plausible futures).

The other methods that were used during foresight including use cases, using a whiteboard, and business model canvas were also related to the scenario development. The last two methods were described as tools that assisted in generating and assessing the scenarios. For instance, they helped the opportunity seekers to put the inputs together to create a holistic vision and try to generate scenarios. These tools were useful during the networking and research actions, as well. Moreover, uses cases technique were pointed out in response to the question about using scenarios and it was considered as a type of scenario development procedure.

Based on the relationships identified among the emergent themes, this research proposes a model indicating a foresight process, which is named "Entrepreneurial Foresight" (Figure 4). In this process, the main purpose is identifying entrepreneurial opportunities. However, it is also used for a couple of strategic purposes. This model by introducing the major inputs, actions, and methods that are used in the foresight process, demonstrates how opportunity seekers conduct the entrepreneurial foresight for the mentioned purposes.

This process starts with inputs that basically play two roles: as material exploited during the actions or/and as leads that initiate and guide the actions. Opportunity seekers may utilize trends and their knowledge to create scenarios leading to future opportunities, or the inputs may motivate them to research and network further to explore the future. So, the L1 link shows both information flow and causal impact. Relating to the causal relationship described above, in some cases, the actions and methods may result in producing inputs. In other words, some of the actions may be taken and some of the methods may be used in order to acquire new inputs. For instance, a person may network or research to learn about other's viewpoints or discover environmental 
changes. Thus, the L2 link indicates a causal relationship. Finally, the last link (L3) indicates what the process leads to (i.e., the ultimate outcomes/objectives). For example, opportunity seekers may exploit the inputs in scenario development so that they can identify opportunities and threats.

\begin{tabular}{|l|l|l|l|l|}
\hline \multicolumn{1}{|c|}{ Inputs } & \multicolumn{1}{|c|}{$\begin{array}{c}\text { Actions \& Methods } \\
\text { - Trends and developments } \\
\text { - Viewpoints and works of } \\
\text { other people and companies } \\
\text { - Prior knowledge and } \\
\text { experience }\end{array}$} & $\begin{array}{l}\text { Petworking } \\
\text { - Research } \\
\text { - Scenario development }\end{array}$ & $\begin{array}{l}\text { Purposes } \\
\text { - Opportunity recognition } \\
\text { - Sustainable opportunities } \\
\text { - Less competitive opportunities } \\
\text { - Market demand } \\
\text { - Evaluating and validating } \\
\text { opportunities } \\
\text { - Risk management } \\
\text { - Financial forecast }\end{array}$ \\
\hline
\end{tabular}

Figure 4 - Entrepreneurial Foresight process

In order to ensure the trustworthiness of study, two methods including thick description and peer debriefing have been used. In accordance with the first method, the researcher attempted to provide detailed and inclusive descriptions about most of the phases and aspects of research. So, readers would have adequate information to be able to assess the trustworthiness aspects. Besides, in peer debriefing technique, a disinterested and experienced scholar with experience in qualitative research assisted the researcher throughout the data analysis phase. The process and results of peer debriefing have been fully explained in the methodology section. The peer by challenging the assumptions and offering different perspectives enabled the researcher to consider alternative analysis and refine the findings. Thus, this method helped to meet trustworthiness criteria, particularly the dependability, credibility, and confirmability. As mentioned before, also the frequent debriefing sessions between the researcher and his supervisor made a major 
contribution to the trustworthiness. The feedback and additional perspectives that were provided by the supervisor challenged the researcher and helped him to ensure the credibility and confirmability of study.

\section{Contradictions}

The results indicated that there were some contradictions in the interviewed data. The major inconsistency was between the answers to the questions (i.e., the general statements) and the actual examples the participants provided to elaborate their earlier statements. Besides, there was a minor inconsistency which was between the earlier answers and the following general explanations. This contradictions can be classified into two types: 1) some participants answered that they apply foresight in opportunity recognition, but their actual examples or following explanations implied that they did/apply foresight for purposes other than opportunity recognition; 2) some participants claimed that they tend to be future-oriented in opportunity recognition, but their actual examples or following explanations implied that they are not really future-oriented.

Two different possible origins of the contradictions are discussed here. First, the participants probably responded inaccurately or falsely to the questions (i.e., incorrect general statement). This could happen due to response biases such as social desirability, demand characteristics, and acquiescence bias (Paulhus, 1991, Orne, 2009); or because of low selfawareness. The second origin, which is not applicable to the minor contradiction, is that the participants may have failed to provide relevant examples (i.e., example of how they applied foresight and identified future opportunities). Because probably they could not remember appropriate examples at that moment, or they didn't have such successful experience theretofore. Therefore, failing to give actual examples that support their earlier answers does not necessarily mean that their answers were false. 


\section{Research limitations}

The lack of adequate prior research on the topic, which could assist in understanding the concepts more thoroughly and subsequently designing more appropriate research, negatively affected the data collection process, especially in term of sampling and creating the interview guide. This shortcoming led to the limitations concerned with the sufficiency and quality of the interview data. First, the interviews were rather shorter than expected and they did not provide very inclusive and diverse information about the topic. Secondly, the existent contradictions in the data set might diminish its quality. However, it highly dependents on the origin of contradictions that were discussed in this section. Finally, the time and resources constraints did not allow the researcher to work further on the research and investigate the new aspects of the topic that came up after the data analysis. The above limitations could weaken the trustworthiness of study and undermine the findings. In particular, the inadequacy and inaccuracy of data might affect the credibility and transferability of the results. Additionally, the limitations have hindered the study from developing a more comprehensive and representative model. 


\section{CONCLUSION}

This study intended to investigate if and why opportunity seekers apply foresight to identify entrepreneurial opportunities and, more importantly, how they accomplish that. These questions have been considered for addressing the knowledge gap existed in both opportunity recognition and foresight areas. The prior research studies on opportunity recognition have not considered the potential role of foresight in this process. Besides, most of the previous research on foresight have overlooked its function in identification of opportunities.

This research shed light on the significance of the future in the process of entrepreneurial opportunity recognin and showed that opportunity seekers apply foresight to identify future opportunities. Moreover, various opportunity-related and strategic purposes for doing the entrepreneurial foresight have been discovered in this study. Most importantly, the research successfully developed a process that contains the key components of the entrepreneurial foresight and the relationships among them. Indeed, this process demonstrated how opportunity seekers apply foresight. 


\section{APPENDIX}

\section{Appendix - Interview guide}

1. Are you more concerned about trying to spot opportunities in the current environment or that might occur in the future?

Participant: In the future.

Researcher: Why future?

$\mathrm{R}$ : Why not the current environment?

R: Can you give an example?

$P$ : In the current environment.

$\mathrm{R}$ : Why the current environment?

R: Why not future?

2. How do you explore the future?

R: What process do you follow? (To clear up the question or help to talk more, if needed) R: Do you use particular methods/tools? (To clear up the question or help to talk more, if needed)

$\mathrm{R}$ : Can you explain it more with an example?

3. How do you visualize different plausible futures?

$\mathrm{R}$ : What process do you follow? (If needed, to clear up the question or help to talk more)

R: Do you use particular methods/tools? (If needed, to clear up the question or help to talk more)

R: Can you give an example to illustrate?

4. Do you ever use scenarios to visualize different plausible futures?

P: Yes.

R: How do you use scenario thinking/development?

R: Can you give an example?

$\mathrm{R}$ : What are the possible outcomes of scenarios thinking/development?

R: How do scenarios help you with identification of new opportunities? 
P: No.

R: Are you familiar with the concept of "scenario thinking" or "scenario development"?

P: Yes.

$\mathrm{R}$ : What does it mean to you?

$\mathrm{R}$ : Do you think it may be useful in opportunity identification? 


\section{REFERENCES}

Alsos, G. A.; Kaikkonen, V. (2004), Opportunities and prior knowledge: A study of experienced entrepreneurs, Frontiers of Entrepreneurship Research, 24(1), 301-314.

Alvarez, S. A., \& Barney, J. B. (2007). Discovery and creation: Alternative theories of entrepreneurial action. Strategic entrepreneurship journal, 1(1-2), 11-26.

Amsteus, M. (2008). Managerial foresight: concept and measurement. Foresight, 10(1), 53-66.

Andersen, P. D., \& Borup, M. (2009). Foresight and strategy in national research councils and research programmes. Technology Analysis \& Strategic Management, 21(8), 917-932

Andriopoulos, C., \& Gotsi, M. (2006). Probing the future: Mobilising foresight in multiple-product innovation firms. Futures, 38(1), 50-66.

Ardichvili, A., \& Cardozo, R. N. (2000), A model of the entrepreneurial opportunity recognition process, Journal of Enterprising culture, (8)2, 103-119.

Ardichvili, A., Cardozo, R., \& Ray, S. (2003), A theory of entrepreneurial opportunity identification and development, Journal of Business venturing, 18(1), 105-123.

Baron, R. A. (2006), Opportunity recognition as pattern recognition: How entrepreneurs connect the dots to identify new business opportunities, The Academy of Management Perspectives, 20(1), 104-119.

Battistella, C. (2014). The organisation of Corporate Foresight: A multiple case study in the telecommunication industry. Technological Forecasting and Social Change, 87, 60-79.

Becker, P. (2002). Corporate foresight in Europe. A First Overview, RTK2 Scientific and Technological Foresight, European Commission.

Berkhout, F., \& Hertin, J. (2002). Foresight futures scenarios: developing and applying a participative strategic planning tool. Greener Management International, 37-53.

Bishop, P., Hines, A., \& Collins, T. (2007). The current state of scenario development: an overview of techniques. foresight, 9(1), 5-25.

Braun, V., \& Clarke, V. (2006). Using thematic analysis in psychology. Qualitative research in psychology, 3(2), 77-101.

Burt, G., Wright, G., Bradfield, R., Cairns, G., \& Van Der Heijden, K. (2006). The role of scenario planning in exploring the environment in view of the limitations of PEST and its derivatives. International Studies of Management \& Organization, 36(3), 50-76. 
Cohen, W. M., \& Levinthal, D. A. (1990). Absorptive capacity: A new perspective on learning and innovation. Administrative science quarterly, 128-152.

Cook, C. N., Inayatullah, S., Burgman, M. A., Sutherland, W. J., \& Wintle, B. A. (2014). Strategic foresight: how planning for the unpredictable can improve environmental decisionmaking. Trends in ecology \& evolution, 29(9), 531-541.

Corbett, A. C. (2005), Experiential learning within the process of opportunity identification and exploitation, Entrepreneurship Theory and Practice, 29(4), 473-491.

Corbett, A. C. (2007), Learning asymmetries and the discovery of entrepreneurial opportunities, Journal of Business Venturing, 22(1), 97-118.

Cuhls, K. (2003). From forecasting to foresight processes - new participative foresight activities in Germany. Journal of Forecasting, 22(2-3), 93-111.

Da Costa, O., Warnke, P., Cagnin, C., \& Scapolo, F. (2008). The impact of foresight on policymaking: insights from the FORLEARN mutual learning process. Technology Analysis \& Strategic Management, 20(3), 369-387.

Darkow, I. L. (2015). The involvement of middle management in strategy developmentDevelopment and implementation of a foresight-based approach. Technological Forecasting and Social Change, 101, 10-24.

Dimov, D. (2007), Beyond the single-person, single-insight attribution in understanding entrepreneurial opportunities, Entrepreneurship Theory and Practice, 31(5), 713-731.

Eckhardt, J. T., \& Shane, S. A. (2003). Opportunities and entrepreneurship. Journal of management, 29(3), 333-349.

Fiet, J. O. (2007). A prescriptive analysis of search and discovery. Journal of Management Studies, 44(4), 592-611.

Foster, M. J. (1993). Scenario planning for small businesses. Long Range Planning, 26(1), 123129.

Francis, J. J., Johnston, M., Robertson, C., Glidewell, L., Entwistle, V., Eccles, M. P., \& Grimshaw, J. M. (2010). What is an adequate sample size? Operationalising data saturation for theory-based interview studies. Psychology and Health, 25(10), 1229-1245.

Gaglio, C. M., \& Katz, J. A. (2001), The psychological basis of opportunity identification: Entrepreneurial alertness, Small business economics, 16(2), 95-111. 
Gasson, S. (2004). Rigor in grounded theory research: An interpretive perspective on generating theory from qualitative field studies. The handbook of information systems research, 4, 79-102.

Georghiou, L., \& Harper, J. C. (2011). From priority-setting to articulation of demand: Foresight for research and innovation policy and strategy. Futures, 43(3), 243-251.

Godet, M., \& Roubelat, F. (1996). Creating the future: the use and misuse of scenarios. Long range planning, 29(2), 164-171.

Guba, E. G. (1981). Criteria for assessing the trustworthiness of naturalistic inquiries. ECTJ, 29(2), 75.

Habegger, B. (2010). Strategic foresight in public policy: Reviewing the experiences of the UK, Singapore, and the Netherlands. Futures, 42(1), 49-58.

Hajizadeh, A., \& Zali, M. (2016). Prior knowledge, cognitive characteristics and opportunity recognition. International Journal of Entrepreneurial Behavior \& Research, 22(1), 63-83.

Hansen, D. J., Lumpkin, G. T., \& Hills, G. E. (2011). A multidimensional examination of a creativity-based opportunity recognition model. International Journal of Entrepreneurial Behavior \& Research, 17(5), 515-533.

Havas, A., Schartinger, D., \& Weber, M. (2010). The impact of foresight on innovation policymaking: recent experiences and future perspectives. Research Evaluation, 19(2), 91-104.

Heger, T., \& Rohrbeck, R. (2012). Strategic foresight for collaborative exploration of new business fields. Technological Forecasting and Social Change, 79(5), 819-831.

Heiko, A., Vennemann, C. R., \& Darkow, I. L. (2010). Corporate foresight and innovation management: A portfolio-approach in evaluating organizational development. Futures, 42(4), 380-393.

Heinonen, J., Hytti, U., \& Stenholm, P. (2011). The role of creativity in opportunity search and business idea creation. Education+ Training, 53(8/9), 659-672.

Hilbert, M., Miles, I., \& Othmer, J. (2009). Foresight tools for participative policy-making in inter-governmental processes in developing countries: Lessons learned from the eLAC Policy Priorities Delphi. Technological Forecasting and Social Change, 76(7), 880-896.

Hills, G. E., Lumpkin, G. T., \& Singh, R. P. (1997). Opportunity recognition: Perceptions and behaviors of entrepreneurs. Frontiers of entrepreneurship research, 17(4), 168-182.

Horton, A. (1999). A simple guide to successful foresight. foresight, 1(1), 5-9. 
Jarke, M., Bui, X. T., \& Carroll, J. M. (1998). Scenario management: An interdisciplinary approach. Requirements Engineering, 3(3), 155-173.

Kaish, S., \& Gilad, B. (1991), Characteristics of opportunities search of entrepreneurs versus executives: Sources, interests, general alertness, Journal of business venturing, 6(1), pp. 45-61.

King, N. (2004). Using templates in the thematic analysis of text. Essential guide to qualitative methods in organizational research, 2, 256-70.

Kirzner, I. M. (1979), Perception, opportunity, and profit: Studies in the theory of entrepreneurship, University of Chicago Press, Chicago.

Kirzner, I.M. (1973), Competition and Entrepreneurship, University of Chicago press, Chicago.

Könnölä, T., Scapolo, F., Desruelle, P., \& Mu, R. (2011). Foresight tackling societal challenges: Impacts and implications on policy-making. Futures, 43(3), 252-264.

Krefting, L. (1991). Rigor in qualitative research: The assessment of trustworthiness. American journal of occupational therapy, 45(3), 214-222.

Lindgren, M., \& Bandhold, H. (2003). Scenario planning. Palgrave.

Magruk, A. (2015). The process of selection of the main research methods in foresight from different perspectives. Business, Management and Education, 13(2), 234.

Major, E., Asch, D., \& Cordey-Hayes, M. (2001). Foresight as a core competence. Futures, 33(2), 91-107.

Marvel, M. R., \& Lumpkin, G. T. (2007), Technology entrepreneurs' human capital and its effects on innovation radicalness, Entrepreneurship Theory and Practice, 31(6), 807-828.

Nowell, L. S., Norris, J. M., White, D. E., \& Moules, N. J. (2017). Thematic Analysis: Striving to Meet the Trustworthiness Criteria. International Journal of Qualitative Methods, 16(1), 1609406917733847.

Orne, M. T. (2009). Demand characteristics and the concept of quasi-controls. Artifacts in Behavioral Research: Robert Rosenthal and Ralph L. Rosnow's Classic Books, 110, 110-137.

Ozgen, E., \& Baron, R. A. (2007). Social sources of information in opportunity recognition: Effects of mentors, industry networks, and professional forums. Journal of business venturing, 22(2), 174-192.

Palinkas, L. A., Horwitz, S. M., Green, C. A., Wisdom, J. P., Duan, N., \& Hoagwood, K. (2015). Purposeful sampling for qualitative data collection and analysis in mixed method implementation 
research. Administration and Policy in Mental Health and Mental Health Services Research, 42(5), 533-544.

Passey, S. J., Goh, N., \& Kil, P. (2006, June). Targeting the innovation roadmap event horizon: Product concept visioning \& scenario building. In Management of Innovation and Technology, 2006 IEEE International Conference on (Vol. 2, pp. 604-607). IEEE.

Paulhus, D. 1991. Measurement and control of response bias. In Measures of personality and social psychological attitudes, Vol. 1, ed. J. Robinson, P. R. Shaver, and L. S. Wrightsman, 1759. New York: Academic Press

Pillkahn, U. (2008). Using trends and scenarios as tools for strategy development: shaping the future of your enterprise. John Wiley \& Sons.

Pinter, D. (2013, January). Applications, Limitations and Effects of Corporate Foresight Methods-Towards an Evaluation Framework for Innovation Management. In ISPIM Conference Proceedings (p. 1). The International Society for Professional Innovation Management (ISPIM).

Pirttimäki, A. (2006). Foresight in a research and technology organisation. Espoo: Helsinki University of Technology [cited 10 April 2012]. Available from Internet: http://www. sal. tkk. fi/publications/pdffiles/tpir06. pdf.

Politis, D. (2005), The process of entrepreneurial learning: a conceptual framework, Entrepreneurship theory and practice, 29(4), 399-424.

Popper, R. (2008a). Foresight methodology. The handbook of technology foresight, 44-88.

Popper, R. (2008b). How are foresight methods selected?. foresight, 10(6), 62-89.

Porter, A. L. (2010). Technology foresight: types and methods. International Journal of Foresight and Innovation Policy, 6(1-3), 36-45.

Rappert, B. (1999). Rationalising the future? Foresight in science and technology policy coordination. Futures, 31(6), 527-545.

Reger, G. (2001). Technology foresight in companies: from an indicator to a network and process perspective. Technology Analysis \& Strategic Management, 13(4), 533-553.

Rohrbeck, R. (2012). Exploring value creation from corporate-foresight activities. Futures, 44(5), 440-452.

Rohrbeck, R., \& Gemünden, H. G. (2011). Corporate foresight: Its three roles in enhancing the innovation capacity of a firm. Technological Forecasting and Social Change, 78(2), 231-243. 
Rohrbeck, R., Battistella, C., \& Huizingh, E. (2015). Corporate foresight: An emerging field with a rich tradition. Technological Forecasting and Social Change, 101, 1-9.

Ruff, F. (2006). Corporate foresight: integrating the future business environment into innovation and strategy. International Journal of Technology Management, 34(3-4), 278-295.

Sarasvathy, S. D. (2001). Causation and effectuation: Toward a theoretical shift from economic inevitability to entrepreneurial contingency. Academy of management Review, 26(2), 243-263.

Schoemaker, P. J. (1995). Scenario planning: a tool for strategic thinking. Sloan management review, 36(2), 25-41.

Schumpeter, J. (1934). Capitalism, socialism, and democracy.

Schwarz, P. (1991). The art of the long view: planning for the future in an uncertain world. Currency Doubleday, New York.

Shane, S. \& Venkataraman, S. (2000), The promise of entrepreneurship as a field of research, Academy of Management Review, 25(1), 217-226.

Shane, S. (2000), Prior knowledge and the discovery of entrepreneurial opportunities, Organization science, 11(4), 448-469.

Shane, S. A. (2003), A general theory of entrepreneurship: The individual-opportunity nexus, Edward Elgar Publishing.

Shenton, A. K. (2004). Strategies for ensuring trustworthiness in qualitative research projects. Education for information, 22(2), 63-75.

Shepherd, D. A., \& DeTienne, D. R. (2005), Prior knowledge, potential financial reward, and opportunity identification, Entrepreneurship theory and practice, 29(1), 91-112.

Singh, R. P. (2000). Entrepreneurial opportunity recognition through social networks. Psychology Press.

Slaughter, R. (1995). The foresight principle: Cultural recovery in the 21 st century. Praeger Publishers.

Slaughter, R. A. (2004). Towards integral futures. Futures Beyond Dystopia: Creating Social Foresight, Routledge Falmer, London, 152-166.

Tang, J. (2009). Exploring the constitution of entrepreneurial alertness: The regulatory focus view. Journal of Small Business \& Entrepreneurship, 22(3), 221-238. 
Tang, J., \& Murphy, P.J. (2012), Prior knowledge and new product and service introductions by entrepreneurial firms: The mediating role of technological innovation, Journal of Small Business Management, 50(1), 41-62.

Tang, J., Kacmar, M., \& Busenitz, L. (2012), Entrepreneurial alertness in the pursuit of new opportunities, Journal of Business Venturing, 27(1), 77-94.

Thomas, D. R. (2006). A general inductive approach for analyzing qualitative evaluation data. American journal of evaluation, 27(2), 237-246.

Tsoukas, H., \& Shepherd, J. (2004). Organisations and the future: from forecasting to foresight. Management Today, 20(7), 18-23.

Valliere, D. (2013). Towards a schematic theory of entrepreneurial alertness. Journal of Business Venturing, 28(3), 430-442.

Valliere, D. (2013). Entrepreneurial alertness and paying attention. Journal of Enterprising Culture, 21(01), 1-17.

Valliere, D. (2011, March). Entrepreneurial alertness through cognitive schemata. In 2nd International Conference on Business and Economic Research (2nd ICBER 2011) Proceeding. Conference Master Resources, 476-485

Vecchiato, R. (2012). Environmental uncertainty, foresight and strategic decision making: An integrated study. Technological Forecasting and Social Change, 79(3), 436-447.

Venkataraman, S. (1997), The distinctive domain of entrepreneurship research, Advances in entrepreneurship, firm emergence and growth, 3(1), 119-138.

Warnke, P., \& Heimeriks, G. (2008). Technology foresight as innovation policy instrument: learning from science and technology studies. In Future-Oriented Technology Analysis (pp. 7187). Springer Berlin Heidelberg.

Wilkinson, A., \& Eidinow, E. (2008). Evolving practices in environmental scenarios: a new scenario typology. Environmental Research Letters, 3(4), 045017.

Will, M. (2008). Talking about the future within an SME? Corporate foresight and the potential contributions to sustainable development. Management of Environmental Quality: An International Journal, 19(2), 234-242.

Wing Yan Man, T. (2006). Exploring the behavioural patterns of entrepreneurial learning: A competency approach. Education+ Training, 48(5), 309-321. 